\title{
IRISH STUDIES ROUND THE WORLD - 2017
}

\section{Christina Hunt Mahony (ed.)}

Copyright (c) 2018 by the authors. This text may be archived and redistributed both in electronic form and in hard copy, provided that the author and journal are properly cited and no fee is charged for access.

\section{Introduction}

Christina Hunt Mahony 200

Colum McCann's Intertexts. "Books Talk to One Another"

Bertrand Cardin

Asier Altuna-García de Salazar

The Lesser Bohemians

Eimear McBride

Silvia Antosa

The Oxford Handbook of Modern Irish History

Alvin Jackson, ed.

Pauline Collombier-Lakeman .208

Time Pieces: A Dublin Memoir

John Banville

Gerald Dawe

All We Shall Know

Donal Ryan

Margarita Estévez-Saá

Silence in Modern Irish Literature

Michael McAteer, ed.

Robert Finnigan 
Sources and Style in Moore's Irish Melodies

Una Hunt

Seán Mac Liam.

\section{The Oxford Handbook of Modern Irish Theatre}

Nicholas Grene and Chris Morash, ed.

Martine Pelletier 222

\section{Modernist Afterlives in Irish Literature and Culture \\ Paige Reynolds, ed.}

Melania Terrazas 226

Introduction: 2017 - The Year in Irish Studies

\section{Christina Hunt Mahony}

In the year following Ireland's very successful commemorative programmes on the centenary of the Easter Rising, commemorations continue and shall continue to do so for nearly another decade, marking World War I, the signing of the Anglo-Irish Treaty, the Civil War and other events. Events of a commemorative nature in the latter part of 2016, not recorded in this space last year, include, most notably, the much-anticipated opening of the Seamus Heaney centre, The HomePlace, located on the site of a former RUC barracks near the poet's childhood home. Among the initial offerings featured poet Paul Muldoon's response to Heaney's final collection, The Human Chain; a selection of Homeric inspired readings, by Adrian Dunbar, relating to Heaney's plays and poems on classical themes; and a reading by Bernard McLaverty from his new novel Midwinter Break. It had been sixteen years since McLaverty, who now resides in Scotland, had published a novel.

Poetry Ireland has moved to its new premises in Parnell Square near The Writers' Centre. Among other recent programmes sponsored was Paul Muldoon's road show, entitled Muldoon's Picnic. Originally on offer in New York, it was a week of readings and music by a large and changing cast of artists, including Anne Enright, Michael Longley, Paul Murray and Muldoon's band, Rogue Oliphant with Cait O'Riordan of The Pogues, as it moved to five venues around the country in August and September of this year. And in October another sponsored event, attended by family members and others, celebrated the $90^{\text {th }}$ birthday of poet Richard Murphy, now resident once again in Sri Lanka. A collection to honour the poet on the occasion, edited by Ben Keatinge, Making Integral: Critical Essays on Richard Murphy, will be published by Cork University Press in 1918.

Other poetry news includes the much-welcomed return on the "Poetry Programme" on RTE's Radio One, with new presenter Olivia O'Leary. The programme, broadcast at 7:30 on Saturday nights, is available on the RTE Player and has thus far showcased old poetry hands like Belfastman Frank Ormsby, and writers whose debut collections are just appearing, such 
as Sligo poet Elaine Cosgrove's Transmissions, and Annemarie Ní Chuirreáin from Donegal with her new volume, Bloodroot.

Possibly the most important cultural event of the 2017 calendar was the muchanticipated re-opening of the National Gallery of Ireland after a four-year refurbishment. The new exhibition spaces are a must-see on any upcoming visit to Dublin, and Irish visitors have already rejoiced in the splendid opening Vermeer exhibit, followed shortly by a display of the works of Irish artist Frederick Burton. The museum's restored courtyard space is made most gracefully complete by a sculptural work, Magnus Modus, by Joseph Walsh whose furniture and woodturning studio in Kinsale attracts artists from around the world.

Recent milestones in the Irish cultural world included a conference in The National Library in September to mark the retirement and life achievement of Roy Foster, Oxford historian and Yeats biographer. Convened by Catriona Crowe, formerly of The National Archives, tributes and papers in a variety of areas of historical and literary interest were presented by colleagues, friends and former students.

November was marked by a conference in Trinity College on the centenary of the birth of writer and statesman Conor Cruise O'Brien, with the O'Brien family in attendance; and, in his native Monaghan on the $50^{\text {th }}$ anniversary of his death, poet Patrick Kavanagh was remembered in a weekend programme of poetry, lectures and music.

Indeed the universities in the past year have done a great deal to observe various anniversaries and centenaries. UCD's Press has distinguished itself of late with the publication of Carla King's biography of Michael Davitt: After the Land League, 1882-1906, an impressive volume of the writings of Hannah Sheehy Skeffington and by continuing to add to its series of Ireland Chair of Poetry publications. The launch of the Skeffington volume at the Royal Irish Academy on Dawson Street featured a learned and lively panel discussion of the legacy of suffragettes and activists such as Skeffington, chaired by Martina Devlin and featuring the volume's editor Margaret Ward, archivist Catriona Crowe and Senator Ivana Bacik. The Ireland Chair of Poetry series published volumes of lectures by former holders of the chair, Nuala Ní Dhomhaill, Harry Clifton and John Montague, with the incumbent, poet Eiléan Ní Chuilleanáin, doing the honours.

Meanwhile down the road in Trinity the college's library was delighted to take possession of the full archive of theatre company Rough Magic - in attendance were Rough Magic founders and Trinity Graduates Lynn Parker and Declan Hughes. Weeks later, in Trinity's Long Room Hub, Fintan O'Toole launched Nicholas Grene's most recent book, Tom Murphy: Playwright and Adventurer, a part of the Bloomsbury Methuen Drama series.

One of the general editors of that Methuen series is Professor Patrick Lonergan who has recently overseen the long-awaited formal opening of the O'Donoghue Centre for Drama, Theatre and Performance on the campus of NUIG. The building was voted the public's choice of Ireland's Favourite Building in a competition run by the Royal Institute of Architects of Ireland.

And no yearly round-up of Irish cultural events would be complete without a brief account of this year's Dublin Theatre Festival. To give just a brief account of what Dublin audiences could sample one could start with Landmark Production's staging of Woyzeck in Winter, a musical, starring the stunning pairing of Camille O'Sullivan and Patrick O'Kane in Conall Morrison's inspired adaptation of Büchner's play fused with Shubert's Winterreise song cycle. The production was noteworthy in that it marked the return of Irish veteran actress Rosaleen Linehan to the stage. Yet another adaptation of a European classic, Corn Exchange's Nora, a version of Ibsen's A Doll's House, was written by Belinda McKeon, and starred Annie Ryan (who also directed) as a middle-aged Nora in an embattled family dynamic including a teenaged daughter (newcomer Venetia Bowe). This year's theatre festival season also saw the return to the stage (in the authorial sense) of Sebastian Barry 
whose On Blueberry Hill was a fine example of dialogic tension in a two-hander by Niall Buggy and David Ganly as unlikely prison cell inmates.

Another veteran Irish writer not exclusively known for his stage work, Dermot Bolger, bravely entered the ranks of those who have penned dramatizations of Joyce's works. Bolger's Ulysses at the Abbey, was a rambunctious commedia delle arte treatment of the classic Dublin novel that worked a treat. And after the Dublin theatre goers bid farewell to the Theatre Festival for another year, they could then travel south to The Wexford Opera Festival for more Joyce in Andrew Synott's operetta Dubliners, with libretto by Arthur Riordan. Directed by Annabelle Comyn, the piece comprised renderings of Joyce's "Counterparts" and "The Boarding House" that were both plangent and sustained by humour in turn.

Christina Hunt Mahony is Senior Research Fellow at the School of English, Trinity College Dublin. She has taught at the University of Illinois at Chicago, Georgetown University, and The Catholic University of America in Washington D.C. She is the author of Contemporary Irish Literature: Transforming Tradition (St Martin's, 1999), and the editor of Out of History: Essays on the Writing of Sebastian Barry (Carysfort Press, 2006) and Report of the Irish Forum: The Future of Irish Studies (Prague, 2006). Dr. Mahony is a member of the Executive of the International Association for the Study of Irish Literatures and sits on the editorial boards of the Canadian Journal of Irish Studies and Estudios Irlandeses.

cmahony@tcd.ie

Colum McCann's Intertexts. "Books Talk to One Another"

Bertrand Cardin

Cork: Cork University Press, 2016. 240 pp.

ISBN: 978-1-78205-224-1

Reviewer: Asier Altuna-García de Salazar (Universidad de Deusto)

Bertrand Cardin's Colum McCann's Intertexts. "Books Talk to One Another" presents a series of individual chapters on the way in which intertextuality features in McCann's oeuvre. This comprehensive and detailed study approaches intertextuality in depth and establishes the idea of the "talkative text" as it is understood and developed by McCann in his writings over time. The present analysis expands on the examination of the decoding of McCann's works, especially as they refer to other works or even quote from them directly or indirectly. As the author contends, the intertextual approach this monograph offers has a twofold aim. On the one hand, it implies a critical analysis of McCann's writings. On the other, the intention is also educational. Accordingly, the volume has the ultimate objective to bring to light and "out of the shade" a comprehensive intertextual reading of McCann's work that has been needed. This monograph constitutes, thus, a salient contribution to many other studies that have Colum McCann's fiction as their main object of analysis. However, the volume asserts that texts are always in contact and dialogue with other texts and have to be approached in this way too. This monograph does not deal with translations, general motifs or other references to music or film which have already been covered by other studies on McCann. Rather, the author prefers to delve into the more fruitful relationships within and between texts that can better illuminate his approach to McCann's fiction. This might seem a flaw of the monograph. However, the author's choice makes this volume a more detailed and analytical study. 
Concepts such as parody, imitation, close allusions, appropriation and transformation are also approached within wider discourses of analysis, as they shed light on sociopolitical and ideological contexts that have Ireland as a backdrop in McCann's writings. As Cardin states, all these help in any approach to intertextuality in which intention and authority are clearly present.

Cardin's study is divided into eleven chapters that deal with different aspects of intertextuality and different works by McCann. The point of perspective is intentionally chronological. The author chooses the dates of publication of McCann's works as this enables a more thorough comprehension of the development of intertextuality in the Irish author's writings. Thus, the volume starts with McCann's 1994 collection of short stories Fishing the Sloe-black River and it ends with another collection of short stories Thirteen Ways of Looking published in 2015. It covers twenty years of McCann's production, which is ongoing, as his latest Letters to Young Writers, recently published in 2017, attests. The eleven chapters in the present volume could be read separately as the intention is to provide a succinct analysis of each of McCann's writings. Warning the reader of the need to have McCann's texts in mind, the author of this present monograph offers rather a didactic analysis that, ultimately, needs to be compared and in dialogue with the own interpretation the reader of this volume may have.

Drawing on the Bakhtinian concept of dialogism and intertextuality the first chapter approaches theoretical tenets such as discourse, polyphony, diphonic discourse, enunciative discourse, memory and parody in McCann's first collection of stories, Fishing the Sloe-black River, published in 1994. The main focus of this chapter rightly assesses parody and transgression in this first collection and compares it with, or rather, sets it within a wider context of, parody and tradition in Irish writing. Drawing on references to Flann O'Brien, Dylan Thomas, and W.B. Yeats, Cardin analyses the voices and echoes that are present in this collection with a close connection to parody. The reader is taken by the hand and shown the multiple intertexts in McCann's work. The chapter ends with a recollection of Gerard Manley Hopkins's "kingfisher" that appeared in McCann's 1997 anthology Phoenix Irish Short Stories. Parody in McCann's early work acts as a revival of and resistance to previous discourses and layers of interpretation, which ultimately enhances cultural exchange and intertextuality. From parody Cardin moves to the all-present concept of myth in Irish writing and how this is used in McCann's writing as regards intertextuality. The intertextual echoes of Thomas Moore, Lady Gregory, Marie Heaney and Greg Delanty in McCann's use of The Children of Lir in his story "Cathal's Lake" recall McCann's own adaptation of this legend, and how it mixes fantasy, folklore and a more intricate comparison between tale and short story. Myth, legend and tale bring together the concept of an eternal Ireland that Cardin recalls in his intertextual analysis. Chapter three engages with the idea of dislocation and intertextuality. The idea of fragmentation is present in McCann's early short stories and this is put into perspective when Cardin links oral storytelling with written storytelling. But, Cardin moves forward in the historical and social development of Ireland over time in his analysis of Everything in this Country Must (2000), from the colonial legacy to the reality of an independent Ireland fraught with economic and social issues, the denominational confrontation over time and its clear consequence in "The Troubles". Intertextuality in this chapter takes us to allusions to and echoes of Paul Muldoon, Shakespeare, Sean O'Casey and James Joyce among others as a means to examine dislocation in McCann's collections of short stories.

Family and family members have featured heavily in Irish writing with dysfunction and guilt ever present. Chapter four approaches McCann's 1995 novel Songdogs by looking at the figure of the Irish father and the intertextual connections it offers. Moving back and forward in the life and history of the protagonist, Conor, Cardin locates intertextuality with constant references to Biblical passages and even mythological legends of Celtic origin, 
especially those of the Cycle of Finn. An interesting analysis of Songdogs and its intertextual relationship with Kerouac's beat generation seminal texts, On the Road and The Dharma Bums, is provided by Cardin, as he rightly approaches McCann's Songdogs as a Bildungsroman. The Bible as it features intertextually covers Cardin's analysis of This Side of Brightness (1998) in chapter five. Constant references and allusions to both the books of the Old Testament and the Gospels appear in McCann's novel, and Cardin here opts for the mytho-critical approach. As found in the Bible, the concepts of destiny, both individual and collective, and the recurrent motifs of death, resurrection and ascension appear in McCann's novel, adapted to provide a clear view to the Irish society of the time.

Colum McCann's Dancer published in 2003 turns a real character, Rudolf Nureyev, into fiction. Accordingly, the book plays between the realms of fiction and verisimilitude. Cardin contends that McCann's use of Diane Solway's biography Nureyev: his Life offers many intertextual echoes within his novel. Besides, intertextuality appears in those books read by the main characters in McCann's 2003 novel - Gorky, Dostoyevsky, Solzhenitsyn and Gogol - although more Western writers are also present. Also closer to non-fiction and real characters is the background of McCann's Zoli (2006), which recalls the story of a real gypsy woman born in Poland, and the subject of a non-fiction book by Isabel Fonseca. As for intertextual references Cardin believes the main motif in Zoli, that of a woman with a tragic destiny, is also close to Hawthorn's The Scarlet Letter. More importantly, Cardin believes that McCann engages in this novel with the representation of minorities, xenophobia, scapegoats and the idea of "the other" as that can also be applied to the stock characterisation of Irish people over time. Both chapters eight and nine in the volume deal with McCann's Let the Great World Spin (2009) from different perspectives. First, authorial assertion and definitions are at stake. Accordingly, Cardin engages in the examination of concepts that are closely linked to intertextuality, such as authorship, exchange and connection. Secondly, Let the Great World Spin offers McCann the possibility to put into action all those intertextual tenets he had been using in previous writings. Thus, parody, voice, and distance evince McCann's intention to approach Ireland and the world after the 9/11 attacks. By so doing, McCann approaches trauma from a different perspective that ultimately needs social cohesion to be healed. The last two chapters in this monograph approach McCann's most recent writings. McCann's 2013 TransAtlantic brings back and forth concepts such as history, characters and generations between two continents. In-betweenness and diversity go hand in hand with the idea of trans- and intertextuality for Cardin. Cardin produces a detailed table with the intentional and clear similarities between McCann's novel and that which can be claimed to be its source, i.e. John Berger's G. (1972). The analysis of Thirteen Ways of Looking (2015) closes this analytical volume on McCann's writings and intertextuality. Cardin believes that this collection of short stories brings the reader once again to multiple references and intertexts that have to be understood to better comprehend McCann's latest work.

Bertrand Cardin's Colum McCann's Intertexts. "Books Talk to One Another" represents, thus, a detailed, illuminating, comprehensive and challenging full-length publication on intertextuality in McCann's works that will help lovers of this Irish author's writings approach his fiction with a new light and fresh perspective. For Cardin, McCann is a clear representative of the postmodern Irish writer as he can establish a dialogue between authority and intertextuality in a new way. The volume's academic depth and didacticism make this volume a clear and definitive exemplar of how McCann's works and intertextuality were in much need of scholarly assessment.

Asier Altuna-García de Salazar is Chairperson of the Spanish Association for Irish Studies, and Associate Professor in English and Irish Studies and Head of the Department of Modern 
Languages and Basque Studies at the University of Deusto, Bilbao. A former Director of the Erasmus Mundus Master of Arts in Euroculture, his publications include articles on 19th century Spain and the Basque Country in Irish writing and multicultural, transcultural and Celtic Tiger Ireland and literature. He has co-edited Re-Writing Boundaries: Critical Approaches in Irish Studies (2007), New Perspectives on James Joyce: Ignatius Loyola, make haste to help me! (2009), and Rethinking Citizenship: New Voices in Euroculture (2013).

asier.altuna@deusto.es

\section{The Lesser Bohemians}

\section{Eimear McBride}

London: Faber and Faber, 2016. 313 pp.

ISBN: 978-0-571-32788-1

\section{Reviewer: Silvia Antosa (Kore University of Enna, Sicily, Italy)}

Published a few years after her first successful novel, A Girl is a Half-formed Thing (2013), which immediately gained critical acclaim, The Lesser Bohemians develops in different and innovative ways some of the themes that Irish author Eimear McBride explored in her previous narrative text. Set in 1990s London, the novel is about a 18-year old Irish girl called Eily who moves to the capital city to study drama and performance. London is described in great detail, as a hectic place full of potentiality, idiosyncrasies and inner contradictions that at once anticipate and mirror the expectations of the protagonist. Once there, she meets a much older man, Stephen, a successful actor who becomes her lover and partner. The first part of the narrative is about Eily's sexual initiation and explores the growing intimacy between the two characters, from their initial sexual encounters to the different, troubling stages which they have to go through in order to get to know each other more deeply and develop a more profound relationship. The detailed account of Eily's own emotional response to the new dynamism of her life of London and her discovery of the pleasures - and challenges - of sex, is followed by a second section which marks a change in focus. It explores Stephen's mysterious past, which is gradually unraveled with its psychological and physical trauma, abuse, drugs and negative, self-harming behaviour. In order to start a love relationship, both characters - and especially Stephen - seem to need to confront their personal traumas to be able to encounter each other on a deeper level.

Events are arranged chronologically over a time span which covers a little more than one year, from 12 March 1994 to 21 July 1995. From a generic viewpoint, The Lesser Bohemians is modelled on the form of the Bildungsroman. Events are arranged into a diegetic structure that recalls the novel of formation, or coming-of-age narrative, in which the (originally male) hero's development requires him to leave both his home and his mother. Finally, after completing his initiation, he is able to return home and embark upon his adult life. From this perspective, the protagonist's move to London marks the beginning of her journey into adulthood. However McBride seems to make clear that the necessary rite of transition from childhood to womanhood for a young girl has to do with sex and sexual awareness, thus challenging the long-standing taboo concerning female sexuality in relation to the process of "education" of women in literature. The novel is full of passages where Eily enjoys her sexual life, from her loss of virginity to a more disinhibited and creative way of making love to her partner. Love, sex and intimacy are explored and experienced in different ways, with their powerful liberating and empowering potential, as it is clear in the following 
exemplifying passage:

Belt first. Next his fly. Both now falling back into time where all the past waits outside. It doesn't matter to me, I say. Then it doesn't matter tonight, he says, now take off your clothes and show me yourself, I want to remember every freckle when you're gone. And I. And bra. Kneels down to my breasts. I. Watch his mouth there. Teeth making twitch running right up to my scalp. How he knows me - and all of me - so much. Kiss. Touch. Already damp his. Slip down where he knelt to. Lick. (124)

Many passages are devoted to the lazy pleasures of days and nights spent by the two lovers in Stephen's room which, far from being a claustrophobic space, becomes a place in which $\mathrm{McBride}$ explores a wide spectrum of emotions ranging from excitement to humour, sadness and even an awareness of precariousness, vulnerability and despair. Yet sex is not only a pleasurable experience. In one of her attempts to take a step back from Stephen in a difficult moment of their relationship, Eily has a one-night stand with a relative stranger whom she meets in a pub. What transpires is a painful encounter that leaves psychological as well as physical marks on her body:

Get off that. Why are you being such a fucking bitch? Oh poor you and your soft little dick. Hey, and I am pushed against the wall I can show you a hard dick if that's want you want. Get off me, I push back. No, him kissing at my neck and Clink through the byre floor, right through my head. Shift spit ert and push from and Get the fuck off! Don't you fucking claw me, and cigarette Jesus right on my arm. You're burning you're fucking burning me! Stop it or I'll scream and. He steps away I wasn't doing anything. You burned me. You fucking burned me! (255)

The moment of sexual and physical violence is reminiscent of the powerfully vivid scenes characterizing the theatre of London-based playwright Sarah Kane, whose plays constitute an important intertextual source for McBride's work. Kane's brutal performances dealt with sexual desire, pain, physical and psychological trauma, bodily torture and - ultimately - death (see for example Blasted, 1995, Phaedra's Love, 1996, and Cleansed, 1998). In so doing, Kane articulated female rage by staging the horrors and the consequences of living through a traumatic event, without any form of mediation. Eily's experience leaves permanent marks on her body, that work as a visible reminder of the gendered power imbalance in violence - and sexual violence in particular.

From the outset of the novel, events are conveyed through the young girl's perspective, as we follow Eily's sexual rite of passage into adulthood and are led into exploring her expectations, ambitions and excitement as a young student of drama. In the first section in particular, McBride struggles against the fixity of syntax in order to convey her first-person intradiegetic narrator's perception, which is articulated through formal incompleteness and half-written sentences. These fragmented and truncated phrases convey Eily's encounter with a totally new sexual life, with its challenges and up-and-downs, as well as her attempt to give shape to the new experiences that she is living, in an attempt to find a sense of order.

The second part of the novel suddenly changes in focus, theme and style. Eily's enthusiasm, her expectations and her somewhat naïve overview of the world are first shattered by the episode of sexual violence and then replaced by Stephen's incredibly dense and traumatic life trajectory that eventually comes out in full force. From a narrative viewpoint, his account is a long-reported monologue, which is followed by his version of a speech by his ex-wife. The different style and tone seem to reflect Stephen's hard experience of the world, 
which has been deeply marked by female figures like his mother and his ex-wife. Sexually and physically abused as a child by his own mother, Stephen manages to escape to London to study drama but becomes a drug addict and is incapable of maintaining his relationship with his girlfriend, with whom he has a daughter. Whereas Eily's voice is marked by incompleteness and fragmentation, Stephen's monologue is instead syntactically linear, with long sentences and a more traditional narrative frame that conceals a very disturbing and densely traumatic personal life story with which he tries to come to terms. As a post-traumatic subject who has not faced and confronted his own past for too many years, Stephen grapples with an overwhelming narrative that generates an outpouring of emotions. In reliving his trauma for the first time, he seems to want to confront it by putting a self-conscious mental distance from it and trying to rebuild a new life for himself.

In terms of narrative balance, in this final section the novel loses part of its stylistic experimental vitality. The first part of the text is driven by McBride's brilliant portrayal of the hectic vitality of the London drama scene of the 1990s through the curious eyes of a young Irish girl who is making her own way in the world. In this second section, however, we encounter a more linear and traditional style that seems intended to reflect the age and experience gap between the two characters. In addition, Eily - who up-to-now has been very reflective and talkative - barely makes any comment or expresses herself in interactions with Stephen. It could be suggested that his story might be too traumatic to be interspersed with further comments, especially by a young, inexperienced character who cannot do much more than report his speech. However, it also seems that Eily sits aside and lets us in: as readers, we are asked to suspend our sense of disbelief and listen together with her to a deeply traumatic story that shakes to its roots our certainties about the meaning of life. In this sense, although differently from her previous novel, McBride continues her narrative search for new ways of articulating the so-called unspeakable core of trauma. In my view, McBride's fiction dramatizes the effects of coming to terms with one's own traumatic past, and her fiction seems to follow Petar Ramadanovic's notion of literature as "a form of turning toward a catastrophe, an instinct, and a desire - an attempt to face them in the most radical and immediate way possible" (113). Both A Girl is a Half-formed Thing and The Lesser Bohemians develop innovative ways of giving voice to traumatic experience by engaging with it in different ways and from varied gendered perspectives.

This is a novel that challenges us as readers to find our own interpretative way into the text. We are compelled to follow the characters' questions and doubts, as well as their exciting happiness that is later mixed with fear, doubt and even violence. McBride is a talented author whose work has the power to challenge us with provocative, intense stories that live with us long after reading and closing the book.

\section{Works cited}

Ramadanovic, Petar. Forgetting Futures. On Memory, Trauma, and Identity. Lanham, MD: Lexington Books, 2001.

Silvia Antosa is Associate Professor of English Literature at the University of Enna "Kore". She is the author of Richard Francis Burton: Victorian Explorer and Translator (Bern: Peter Lang, 2012) and Crossing Boundaries: Bodily Paradigms in Jeanette Winterson's Fiction 1985-2000 (Roma: Aracne, 2008). Antosa is the editor of several interdisciplinary volumes on queer theories and practices; she has published extensively on Victorian fiction, poetry and travel accounts as well as on contemporary British fiction. More recently, she has co-edited a special issue of Textus: English Studies in Italy 1 (2015) on the gender and sexuality in 
modern and contemporary British fiction, with Joseph Bristow (UCLA). She is currently writing a monograph on British Victorian writer Frances Elliot and co-editing a study on the technologies of the body in contemporary Anglo-American representations.

silvia.antosa@unikore.it

\section{The Oxford Handbook of Modern Irish History}

Edited by Alvin Jackson

Oxford: Oxford University Press, 2017 (2014). 786 pp.

ISBN: 978-0-19-876821-0

\section{Reviewer: Pauline Collombier-Lakeman (University of Strasbourg, France)}

In recent years, scholars and students interested in Irish studies have been provided with new overviews of the history of Ireland - for instance Thomas Bartlett's Ireland: A History (Cambridge University Press, 2011) and The Princeton History of Modern Ireland edited by Richard Bourke and Ian McBride (Princeton University Press, 2016). The Oxford Handbook of Modern Ireland, first published in hardback in 2014 and now available in paperback, partakes of this attempt by academics involved in the study of Ireland to renew and update history-writing, which has long been deeply influenced by older seminal works such as, for instance, J. C. Beckett's The Making of Modern Ireland (1966), R. F. Foster's Modern Ireland 1600-1972 (1988) or S. J. Connolly's Oxford Companion to Irish History (1998).

The Oxford Handbook of Modern Ireland is edited by Alvin Jackson, whose previous book Home Rule: an Irish History 1800-2000 brought fresh insight into the history of Irish parliamentary nationalism, and it gathers contributions from 36 scholars, each writing in their area of expertise in and extensive work on the topics they each deal with - amongst many others, Stephen Howe on "Colonised and Colonizers"; Enda Delaney on "Migration and Diaspora"; Maria Luddy on "Gender and Irish History"; Patrick Geoghegan on "Rising and Union, 1791-1801" and Peter Gray on "Famine and Land, 1845-80".

Jackson's introduction is an amazingly concise, yet thorough, examination of the evolution of Irish history writing since the 1930s. His assessment of the legacy left by the historians he names "reformers" - also known as revisionists - is nuanced and deliberately aims at avoiding the intransigence of previous critics of the revisionist school. Jackson acknowledges the importance of the work achieved by the founding fathers of the school and avoids describing it as a monolithic group. The main issue he identifies concerning revisionism is not so much their distrust of nationalist myths as their dominance and influence over Irish history. That Jackson attempts to go beyond the conflict between revisionists and their critics is all the more perceptible as he devotes a few good pages to the latest trends in Irish history - the development of micro-history, the increasing interest in rediscovering Gaelic Ireland and the growing number of transnational studies. The contributors chosen for the volume include representatives of all the various schools of history, which testifies further to the desire not to confine history writing to a single discourse. The aim here is clearly to avoid privileging any particular approach to Irish history writing in order to overcome the strict antagonism between nationalist and revisionist histories and shed light on emerging and fruitful avenues of exploration.

Following the introduction, the volume is divided into two parts. The first is devoted to "thematic issues" such as "Patriotism and Nationalism", "Land and the People", "Business and Industry", "Faith in Ireland, 1600-2000" or "Visual Arts". The second part deals with 
"period studies": four rather traditional timeframes (c. 1580-1690; 1691-1801; 1800-1920 and 1920-2008) are broken into smaller time periods and topics. The emphasis on key concepts in the first part allows the book to review critical aspects of Irish history in more depth and avoid being merely a classically chronological narrative - contrary to many previous studies. However the fact that thematic issues come first also means that this book is better suited for those who already have a strong working knowledge of Irish history.

The Princeton History of Modern Ireland is organized in a similar fashion but with "narrative and events" first and "topics, themes and developments" second. It also shares a few contributors with The Oxford Handbook (Matthew Kelly on the topic of nationalism, Enda Delaney on the Irish diaspora, Maria Luddy on the question of women's history, Diarmaid Ferriter on twentieth and twenty-first century Ireland). But The Oxford Handbook includes a few notable specificities. Many of the thematic chapters present themselves as studies of twinned notions such as "patriotism and nationalism", loyalists and unionists", "colonized and colonizers", "migration and diaspora", etc. This allows a clear and welcome differentiation between - for example - the agenda of $18^{\text {th }}$-century patriotism and later nationalisms, or between the different and successive trends of Irish unionism, of which loyalism was only one of the many defining features. Working on twinned notions also allows the contributors to emphasise the dynamic interactions between diverse historical developments: for instance, Maria Luddy writes about both the participation of women in the making of Ireland and the growing amount of scholarly research devoted to Irish women; and Stephen Howe brings to the fore how Ireland's relation to Britain caused it to take part in British imperial ventures and therefore turned Ireland's position to a hybrid one, creating a multifaceted identity.

A particularly original contribution is Yvonne Whelan's "Landscape and Politics", which focuses on landscapes as objects endowed with political and cultural significance and meaning. This is illustrated by two case studies. First, a study devoted to the $31^{\text {st }}$ Eucharistic Congress held in Dublin in June 1932 reads like a condensed research paper and interestingly postulates that Dublin's geography was used in such a way as to project a specific image for the young Irish Free State - that of a "new, independent and overtly Catholic nation". Whelan then turns to examine the recent work done on the role played by commemorative monuments, which transform particular places into sites of memory and contribute to the elaboration of historical and identity narratives. In both cases, what is emphasised is that landscapes may work as "a stage" where high political and cultural stakes are at play.

A decent share of the volume is also devoted to cultural history, which is not reduced to literature but includes visual arts (by Fintan Cullen) and material cultures (by Toby Barnard), as well as film and broadcast media (by Robert J. Savage). Together with Whelan's paper on landscape and politics, these contributions highlight an attempt at encompassing all the domains of history without exception; they are innovative as they focus on subjects that rarely have been studied per se in previous general histories of Ireland. Similarly in the period studies section, the papers on "Irish-Language Sources for the History of Early Modern Ireland" (by Éamonn Ó Ciardha), on "Ireland and Continental Europe, c. 1600-c. 1750" (by Maurice Bric), "Ireland and the Atlantic World, 1690-1840" (by Nicholas Canny) or "Ireland and First World War" (by Timothy Bowman) provide fresh insights into Irish history. Either they give pride of place to alternative sources for Irish history or they cover smaller timeframes and more precise subjects, which makes for a refreshing contrast to the more traditional accounts that generally divide Irish history into the same broad timeframes and concentrate merely on Ireland and its relationship with England and the rest of the British Isles.

This new book is certainly a crucial and welcome addition to the sources we may resort to and recommend to students in Irish studies. However its close reading elicits one 
small regret. While Alvin Jackson celebrates the "broadening of Irish history" and its "diversity and vitality" (17) and Enda Delaney reminds us that history-writing implies taking into account "many different voices, identities, and variations", it is to be noted that the footnotes and bibliographical references at the end of each chapter rarely mention the research published by scholars and academics involved in Irish Studies outside of the Anglophone world - except Evi Gkotzaridis's major works on Irish revisionism. It is to be hoped that the increasing number of comparative and transnational studies, which the Oxford Handbook recognizes as responsible for invigorating Irish studies, will give non-Anglophone scholars the opportunity to contribute more visibly to the writing of Irish history.

Pauline Collombier-Lakeman is a lecturer at the university of Strasbourg, where she teaches nineteenth- and twentieth-century history of the British Isles and English language. She was awarded her Ph.D from the Université Paris 3 - Sorbonne Nouvelle in 2007. Recent publications include: "Myopia or Utopia? The Discourse of Irish nationalist MPs and the Ulster Question during the Parliamentary Debates of 1912-14", in G. Doherty ed. The Home Rule Crisis 1912-14. Cork: Mercier Press, 2014; and "Irish Nationalist MPs and the Egyptian Revolt of 1881-1882: An Example of Cross-Imperial Solidarity?", in Ibata, Lehni, Moghadassi and Nasiri-Moghaddam, ed. Geographies of Contact: Britain, the Middle East and the Circulation of Knowledge. Strasbourg: Presses Universitaires de Strasbourg, 2017.

collombier@unistra.fr

Time Pieces: A Dublin Memoir

John Banville, with photographs by Paul Joyce

Dublin: Hachette Ireland, 2016. 211 pp.

ISBN: 978-1-473-61904-3

Reviewer: Gerald Dawe (Trinity College Dublin, Ireland)

In my copy of John Banville's novel Kepler published in 1981, the following passage on page 131 is marked in obvious approval:

I keep with me a copy of the engraving by the great Durer of Nuremberg, which is called Knight with Death \& the Devil, an image of stoic grandeur \& fortitude from which I derive much solace: for this is how one must live, facing into the future, indifferent to the terrors and yet undeceived by foolish hopes.

The reference to Durer's The Knight, Death \& the Devil would certainly have resonated with many readers schooled in the UK and Northern Ireland in the 1960s because that aweinspiring engraving accompanied Randall Jarrell's ekphrastic poem of the same name in a much used BBC Schools anthology of the time. Here it was again, blazoned on the cover of a book that richly imagined sixteenth century Germany, and written by an Irish novelist not that much older than ourselves. "A fascinating historical fiction" the blurb had it, "and also a work of art". And was there perhaps a little borrowing going on too - "yet undeceived by foolish hopes" has just a hint of Philip Larkin floating in the background? Maybe not.

Kepler was a bracing, bold artistic act, part of Banville's triptych which included Doctor Copernicus (1976) and The Newton Letter: an interlude (1982). What had gone before 
- Long Lankin (1970), Nightspawn (1971) and Birchwood (1973) - was, in a sense, a preparatory work that led the initiate into Banville's extraordinarily imagined world of mathematics, astronomy and meditations on the meaning of history. None of the Irish "stuff" that, during the 1970s and ' $80 \mathrm{~s}$, was anathema to the yearning younger generation in the country. Banville was cool. That he had a prestigious position as literary editor in The Irish Times suggested an opening up of the mainstream culture to wider, more aesthetic and cosmopolitan pulses: critical philosophy, European and American literature and art, and the local brutal bloody conflict at home found a different kind of imaginative perspective and range. The Troubles became part of a European narrative, not solely the old historical battle between "Ireland" and "England". Stirring times indeed.

With the publication of The Book of Evidence (1989) Banville reached a much wider general audience and appeared to have relented on the big frame of History. He also became a more available presence - giving readings, interviews and the like - altering his style by the 1990s with a series of finely-tuned novels including Ghosts (1993), Athena (1955), The Untouchable (1997) and Eclipse (2000). By the turn of the century, Banville's productivity showed no signs of slowing down with the publication of Shroud (2002) and, in particular, with the international success of his Man-Booker Prize-winning novel, The Sea (2005). Since when Banville has not only published two further novels - The Infinities (2009) and Ancient Light (2012) but also, using the pen name Benjamin Black, has written a group of crime novels featuring Quirke, as his central character - one whom Banville remarks "moves around in that area where I was when I first moved to Dublin". It is at this point of recollection that Banville's memoir, Time Pieces takes its bearing: an annual train journey to Dublin undertaken with his mother and sister from the family home in Wexford on Little Christmas in the 1950s and staying with an aunt in Upper Mount Street. It was also the start of Banville's love affair with Dublin, after he left school and started to work in the city.

I loved the melancholy of those Dublin evenings, despite the weight they laid upon my young heart. Railway stations at night are always incurably sad, and as the train pulled out of Westland Row at the start of the return trip to Wexford, I would have to turn my face away and press it up close against the window to hide my tears from my mother and sister ... thinking back now, I suppose it was because something was ending, was being folded up, like a circus tent; was becoming, in short, the past. (32)

The process of how people and things "become the past" is largely what Time Pieces is about - that and a series of acute observations on particular locations in Dublin which the writer and his friend, "Cicero" (the book's dedicatee, Harry Crosbie, OBE) travel to in a splendid opentop car. Notwithstanding the novelist's reservations about writing about places and people he has known:

I have never in my life paid much attention to my surroundings wherever it was I happened to find myself - artistic attention, that is. For good or ill, as a writer I am and always have been mostly concerned not with what people do - that, as Joyce might say, with typical Joycean disdain, can be left to the journalists - but with what they are. Art is a constant effort to strike past the mere daily doings of humankind in order to arrive at, or at least to approach as closely as possible to, the essence of what it is, simply, to be. (53)

But this is only partially true of Time Pieces since it is full of wonderful mini-portraits of various forms of being such as the electric fire: "Do people use electric fires nowadays? - are they even manufactured anymore?" To which Banville muses: "The thing had the look, to my 
fanciful eye, of one of those garish fly-catching plants that squat in jungle clearing with a glowing red tongue enticingly exposed. It made good toast though, I remember that" (67).

Memories fuel reveries and many epiphanies cascade through the book, though, on the one and only occasion I spotted, the walking narrative recasts the past. "Turning left and immediately right" we are told, "we would come up into Merrion Square, where, at number one, a fine example, at least in its exterior, of a terraced Georgian townhouse, Oscar Wilde was born". Nope. Oscar was born around the corner, in lowly 21 Westland Row, where Speranza hosted her salon, before moving up in the world, and literally around the corner into the temporary good fortune of a much plushier Merrion Square.

Never mind; this is a map of virtual realites and all the more entrancing for so being. There is the equally upended moment as Banville come faces to face in Pearse Street Library with the stone head of Nelson's statue, "only slightly larger than life size":

It stands on a modest plinth in a corner of the Reading Room, ravaged of expression, as is only to be expected - the doughty fellow was blown sky-high, after all. He has been weathered to a hollow-eyed and slack-mouthed starkness; a noticeable feature, or lack of feature, is his missing nose, which, it is said, was shot off by a stray bullet during the 1916 Rising. (127)

It is said, indeed. But the gloss that accompanies this somewhat bizarre encounter makes sense of Time Pieces and draws into the narrator's design a deeper "abiding" artistic interest from which the novelist can't quite depart:

Incongruity, as we know, is one of life's abiding conditions. That I should be standing on a summer afternoon in Dublin City Library viewing the torsoless stone head from a statue to the victor of Trafalgar that fifty years before has been blown off its column in the middle of the night by a gang of IRA wildmen might not be said to rank among the more egregiously unlikely conjunctions I have experienced in my time, but, still, it felt bizarre in the extreme. Borges somewhere remarks how the surface of reality now and then and here and there reveals a tiny crack through which for an instant we catch a glimpse of the possibility of an entirely other order of things. My encounter with Admiral Nelson certainly opened one of those fissures. $(127-28)$

As with Alan Bennet's praise of public libraries, Banville has a good word to say about them; there is too a surprisingly (perhaps) genial sense of life pervasive in the writing as Fifties and Sixties Dublin is recaptured. Which is not to say that the dark side of existence is hopped over. "Under a tyrannical regime", he writes, "and the Ireland of those days was a spiritual tyranny - the populace becomes so cowed that it does the state's work for it voluntarily. And as every tyrant knows, a people's own self-censorship is the kind that works best" (103). Later the Catholic Church's "cover-ups" lead to an aphoristic resolution: "my generation scratched its head and asked, in voices trembling with incredulity, 'How could we let them get away with it for so long?'” (105).

But the question, of course, contained its own answer: We let them get away with it. "Power is more often surrendered than seized" (103). Earlier the "Ireland of the McDaid Age" is described as "a hard, mean-spirited place for anyone with artistic ambitions", and compared with the author's experiences of eastern Europe: they had the Communist Party "invigilating their lives from the cradle to the grave, while we had the Catholic Church doing exactly the same thing" (96). 
The remnants of Southern Irish Protestantism feature in one of the love stories attached to his Dublin memories in the figure of Stephanie, "I wonder if she had a happy life, or at least a not unhappy one. Strange to think of her being somewhere, at this moment, doing something. Stranger still to think of her perhaps not being here; of her not being anywhere" (175). But regret is not the novelist's way. Along with the wonderful black and white photographs of Paul Joyce, Banville has produced a supple, ironising portrait of himself, the city where he lives and continues to work, and the intersections that have played out between them both since he moved there first, young and hopeful.

Gerald Dawe is a Belfast born poet who was professor in English and Fellow of Trinity College Dublin until his retirement in 2017. He has published eight collections with The Gallery Press, including Lake Geneva (2003), Selected Poems (2012) and Mickey Finn's Air (2014). Forthcoming publications include In Another World: Van Morrison and Belfast (Merrion Press) and, as editor, The Cambridge Companion to Irish Poets.

gdawe@tcd.ie

\section{All We Shall Know}

Donal Ryan

London: Doubleday, 2016. 187 pp.

ISBN: 9780857524379

\section{Reviewer: Margarita Estévez-Saá (University of Santiago de Compostela)}

Since Irish literature is one of the most prolific, versatile and brilliant of world literatures, and Irish authors are excelling at diverse literary genres that include the short story, the novel, poetry and theatre, it is certainly difficult to summarize main trends in contemporary Irish writing. Notwithstanding this cautionary precision, any informed reader would agree that we can distinguish a series of authors intent on rewriting, revisiting and revising Ireland's past (Joseph O’Connor, Colm Tóibín, or Emma Donoghue are good examples). Meanwhile others are focused on representing and dissecting in fiction the contemporary circumstances of Ireland and of the Irish (Dermot Bolger, Anne Enright, Deirdre Madden, or Claire Kilroy are significant instances). We could even discern a third group more clearly concerned with deciphering through their protagonists the most subtle intricacies of the human condition, by deploying the most radical crises an individual can experience, and with representing in fiction our most intimate and personal biases. Thus, Deirdre Madden (Molly Fox's Birthday, 2008), Eimear McBride (A Girl Is a Half-Formed Thing, 2013), Caitriona Lally (Eggshells, 2015), Sarah Baume (Spill Simmer Falter Wither, 2015; A Line Made by Walking, 2017) and Donal Ryan belong to a wider group of authors intent on demonstrating the ongoing interest in character in fiction, and Irish writers' particular penchant for and ability to deploy the numberless possibilities of characterization. This is part of a long tradition in Irish writing that probably began with Laurence Sterne's unforgettable Tristram Shandy and acquired maximum expression with James Joyce's creation of the complex and multifaceted Leopold Bloom.

Donal Ryan's Melody Shee, the protagonist of his latest novel to date, All We Shall Know, illustrates the Irish writer's interest in and skills for characterization that were already evinced in his previous novels. Ryan is becoming one of the most promising figures in the contemporary Irish literary scene since his first novel, The Spinning Heart (2012), was listed 
for the Booker Prize in 2013 and won the Guardian First Book Award in that same year. His next novel, The Thing about December (2013), had been written before the first one but discarded by several publishers, and received popular and academic recognition after its publication. The latter novel documents the protagonists' fate during the years of the economic boom, the former life after Ireland's financial collapse. Therefore, the chronological setting of the novels corresponds to the order of their composition rather than to the order of their publication.

Ryan's The Thing about December should be added to that already considerable number of literary works by Irish authors who have recorded the follies of the so-called Celtic Tiger years (such as Mary Rose Callaghan's The Visitors' Book, 2001; Anne Haverty's The Free and Easy, 2006; Éilís Ní Dhuibhne's Fox, Swallow, Scarecrow, 2007; Anne Enright's The Forgotten Waltz, 2004; or Dermot Boger's Tanglewood, 2015). And The Spinning Heart is a further instance of fictions documenting the bleak and tragic socioeconomic aftermath that followed the welfare years (including Dermot Bolger's The Fall of Ireland, 2012; Peter Cunningham's Capital Sins, 2010; Colm Keena's Bishop's Move, 2013; and Claire Kilroy's The Devil I Know, 2012). Donal Ryan's work always manages to offer a different perspective. Most Celtic Tiger fiction depicts how the economic boom affected urban Ireland, whereas Ryan, in The Thing about December, exposes how it also got its claws into the rural areas of the country. In both The Thing about December and The Spinning Heart, the writer's concern is not with greedy property developers, unscrupulous bankers, corrupted politicians or avaricious businessmen but rather with the quiet victims, those who were cheated and exploited by the powerful and the affluent.

Donal Ryan's All We Shall Know shares with his two previous novels Ryan's preference for unlikely heroes, for protagonists who, like Joyce's Mr Duffy in "A Painful Case", feel that they "have been outcast from life's feast". Nevertheless, in contrast with Ryan's previous novels, in which men feature more prominently than women (especially in the case of The Thing about December) the main protagonists of All We Shall Know are two women, Melody Shee, thirty-three, and Mary Crothery, nineteen years old. The story is told from the perspective of the former, who begins her narrative when she is twelve weeks pregnant by a Traveller student of hers, 17-year-old Martin Toppy: "Week Twelve. Martin Toppy is the son of a famous Traveller and the father of my unborn child. He's seventeen, I'm thirty-three. I was his teacher. I'd have killed myself by now if I was brave enough. I don't think it would hurt the baby. His little heart would stop with mine" (7). Formally speaking, the reader will recognize Ryan's recurrent preference for segmenting the representation of his characters' experiences, which is a way of deploying in fiction the fragmentation of our human condition, and his recourse to reproducing the discontinuous, complex and multidimensional nature of the modern self. The Spinning Heart unraveled the tragedy of the Irish economic collapse through the points of view of 21 different victims, and The Thing About December was divided in 12 chapters, each dealing with a month in the life of Johnsey Cunliffe. All We Shall Know begins when Melody is twelve weeks pregnant and the novel is structured in the remaining weeks that cover Melody's pregnancy and finishes with a "Postpartum" concluding section.

Melody is a middle-aged married woman who betrayed her childhood friend Breedie Flynn, is unfaithful to and abuses her husband Pat, ignores her quiet and good-natured father, and is constantly musing over the possibility of committing suicide and putting an end to her life and to that of her unborn child. Even though there is not much to recommend Melody as a fictional representative of the human condition, as the narrative progresses the reader sympathizes with a protagonist whose flaws, weaknesses, and limitations make her all too human. Besides, she could be interpreted as a victim of adverse vital circumstances and wrong choices in life. Melody, who has studied English, history and journalism, writes and 
occasionally publishes poetry, and deploys social concerns related to GM food, whaling, asylum seekers or sexism, does not fit in the small village community in which she lives and has not found an intellectual equal in her affable husband. All this, of course, does not justify the protagonist's cruelty and her inability to search for an alternative way of life out of a suffocating existence. And Melody, who sometimes considers that she is certainly evil - "I'm bad, for sure. There's no kindness in me" $(41)$ - on other occasions considers that she can still be redeemed - "I'm not all bad. I'm not evil or irredeemable" (56) -, devotes her time to scrutinizing and recording both the physical changes her body is experiencing during pregnancy as well as the mental states through which she passes: "all my moments now are marked and measured, standing out in unforgiving light to be examined" (8). It is in fact this narration of her own life that saves Melody from definitive destruction and seems to offer her an alternative way out of her meagre existence: "My mood is lifted this past few days; this writing down of random things is lightening me, pushing me outwards, creating a tension in me that seems to be serving as a kind of exercise, a tearing and reconstituting, a building of something" (39). It is precisely this ability to think, to revise past conducts, to lament and to learn from past deeds and old wrongs, and to change, what makes us human. Melody's friendship with Mary Crothery, the young Traveller girl whom the narrator befriends, will offer her another opportunity to discover kindness, friendship and selflessness.

Ryan's representation of the Irish Traveller community in the novel deserves particular attention. The so-called Travelling People have been traditionally ignored or stereotyped in Irish literature and culture. More recently, we can detect a renewed interest in the representation in fiction of this social group (by authors such as Anne Haverty, or Eílìs Ní Dhuibhne among others). However, their appearance in All We Shall Now is not exempt from controversy, as Ryan describes this group as an illiterate, conservative and patriarchal community that punishes and ostracizes mainly the female members for infractions. Furthermore, Ryan portrays Travellers are being given to vengeance and violence. Despite these negative connotations, the reader should not forget that the perspective offered in the narrative is Melody's and that it is a member of the Travelling People, Mary, who will encourage and inspire a change in the rest of the protagonists, thus facilitating the denouement of the novel's final message seems to be that human redemption is always possible, and that every single man or woman will always have the chance of atonement.

Margarita Estevéz-Saá is Senior Lecturer in English and American Literature at the University of Santiago de Compostela. She has published essays on modernist and postcolonial literature, contemporary Irish literature, critical theory, and feminist criticism.

margarita.estevez.saa@usc.es

Silence in Modern Irish Literature

Edited by Michael McAteer

Leiden: Brill Rodopi, 2017. 220 pp.

ISBN: 9789004342736

Reviewer: Robert Finnigan (University of Sunderland, UK) 
Can the silent speak, if not, who speaks for the silenced? Silence continues to be a foreboding presence in Irish studies. According to Cheryl Glenn, it is important to consider that the "rhetoric of silence" (26) has always relied upon notions of power, authorship, and agency. In an Irish context, it is imperative to understand these notions when appreciating the politics of identity that have shaped modern Ireland, particularly in the spheres of culture, history and literature. Attendees of the Silence ... and Irish Writing conference held at Pázmány Péter Catholic University, Budapest in 2014 will be aware of the recent reflections on forms of silence which signify intimacy, desire, fulfilment, grief, terror, trauma, boredom, linguistic and cultural loss in Irish writing. As such, scholars from a number of disciplines will find this volume, Silence in Modern Irish Literature, filled with new and topical discussions.

Adopting the theme of silence as the conceptual framework for this volume, McAteer begins by discussing a couplet from Austin Clarke's "The Planter's Daughter" (1929) -

Men that had seen her

Drank deep and were silent

McAteer comments thus on these lines:

The silence to which Clarke's lines refer carries a range of meanings that direct readers towards the complexity and the importance of silence in modern Irish literature. These include psychological, ethical, topographical, and spiritual aspects of Irish silence; themes that are explored in the present volumes of essays. (1)

Thus, taken as an exemplar, various readings of Clarke's couplet provide a guiding marker for the introduction. Most notably, considering "The Planter's Daughter" in relation to the Aisling tradition and the figure of the Speirbhean, McAteer writes of: "the traumatic experiences of Irish history latent within the woman as a figure of silence who induces silence in the men who see her" (2). Yet, throughout his commentary on the poem, McAteer provides readings that move beyond static interpretations and illuminates a series of refreshing perspectives regarding the significance of varied silences. In a somewhat surprising omission, however, McAteer does not include a series of aims or rationale for this study, despite the detailed overview of each of the essays contained within this collection.

Divided into four parts, "Psychologies of Silence", "Ethics of Silence", "Places of Silence" and "Spirits of Silence", the essays presented cover the spectrum of modern Irish authors and playwrights. In part 1, McAteer, Emile Morin, Heather Ingman, and Alesandra V. Jovanović explore "the psychological pressures that silence contains for writers from Ireland over the past century", namely W. B. Yeats, Samuel Beckett, Elizabeth Bowen and John Banville (3). Examining Yeats's poem "How Ferencz Renyl Kept Silent" (1887), as well as Cathleen ni Houlihan (1902) and Where There is Nothing (1903), McAteer demonstrates that "How Ferencz" exudes Yeats's contradictory symbolism in which silence is seen as a form of madness and a result of "political violence [and] unspeakable trauma" (23). Next, Ingman, broadly employing Julia Kristeva's theories of language, investigates the conflict between silence and language, and compares the struggling female and dominant male characters in Bowne's The Last September (1929), The Death of the Heart (1939), The Heat of the Day (1949) and Eva Trout; or Changing Scenes (1968). Examining Banville's art trilogy, The Book of Evidence (1989), Ghosts (1993) and Athena (1996) Jovanovic "traces a connection that Banville's novel unfolds between Lacan's notion of a rupture with the external world one that is patched over with fantasy in the psychotic mind - and Agamben's idea of painting as silent poetry" (8). Particularly worthy of note in part 1 is Morin's chapter, "Theatres and Pathologies of Silence: Symbolism and Irish Drama from Maeterlinck to Beckett", in which 
Morin explores the "silent interval that brings to light" (35) the connections between Irish and European dramatic experiments with silence. Morin notes:

There are many striking proximites between ... silence emerging in the new theatre derived from Symbolism and Beckett's later comments on his own plays as driven by forms of secrecy, ambiguity and concealment; forms which he, as the author, was unable to explicate. (45)

Drawing on various strands of Maeterlinck's concept of the theatre as dealing with the unspoken and unexpressed, Morin demonstrates with ease its significance to Beckett's dramas, notably Acts without Words (1957), Waiting for Godot (1953) and Come and Go (1966). Moreover, in her analysis of medical diagnosis that feature in Symbolist literature, Morin highlights the competing and plural manner in which the speech of hysteric patients was taken as a new form of silence and a way of thinking about the voice.

In part 2, Willa Murphy, Mark McGahon, Benjamin Keatinge and Alesandra Boiler centre their attention on the ethics of silence in relation to the Catholic Church, violence and gender. Analysing a range of works by Gerald Griffin, and John and Michael Banim, Murphy argues with conviction that rather than freedom and identity being inimical to secrecy and silence, they are complementary, and the seal of the Confessional is the "emblem of this paradox" (82). Similarly, in his exploration of silence as testimony, Keatinge reads a number of Beckett's plays and Hubert Butler's essays as illustrating their struggle against Nazism during World War II. Considering George Steiner's assertion that silence is "the only plausible response to the Holocaust because language itself has been altered in its essence by the catastrophe" (13), Keatinge argues that Beckett's historical experiences enable him to address the Holocaust and the Anglo-Irish Civil War. Moreover, Keatinge explores Derek Mahon's debt to Beckett in terms of testimony and Mahon's focus on "the large-scale calamities of human history" (13). In Boiler's essay, Roddy Doyle's novels are examined with particular emphasis being given to the workings and maintenance of codes of silence, and the narrative and stylistic manner he uses as examples of domestic violence and female exploitation. McGahan's "Silence, Justice, and the Differend in Joyce's Ulysses" deserves mentioning for his observations about the connections between silence, Irish Nationalism and Catholicism through the lens of Joyce's writings. Focusing on "A Mother" from Dubliners (1914) and the "Nestor" and "Cyclops" episodes in Ulysses (1922), McGahon sensitively illustrates how silence can function as a coercive or liberating force, and how, in conjunction with linguistic ambiguity, such silences emphasise the instability and uncertainties of Ireland's political status.

Moving forward in part 3, Marta Pellérdi, Anne Fogarty and Stephanie Schwerter focus on "how silence in modern Irish writing involves the issue of place" (13). Fogarty investigates Kate O'Brien's The Land of Spices (1941), its status as a banned book because of its homosexual content, and "suggests a correlation between an erotic investment in the father, queer femininity, and the marginalized role of women" (146). Schwerter concentrates on translations of Robert McLiam Wilson's Eureka Street (1996) and explores the challenges of translating aspects of Belfast's urban landscape into differing environments; as well as the examples of silence that arise in the process. As Schwerter observes; "In Wilson's Eureka Street silence manifests itself particularly in the acronyms on Belfast's walls. As territorial indicators, they guide and misguide the novel's characters through coded meanings of urban space" (163). Employing Elisabeth Lovelie's concept of literary silence, Pellérdi's chapter examines the oscillating quality and defamiliarising aspect of silence that transitions from Turgenev to Moore. Pellérdi notes: 
Lovelie sees literary silence as emerging through the interaction of three main factors: "repetition, aporia, and implosion". In this chapter, I adapt these critical terms in discussing silence and displacement in Turgenev's "Kasyan from the Beautiful Lands" and stories from Moore's The Untilled Field, with particular focus on "Home Sickness". (138)

In probing such silences and examples of displacement, Pellérdi highlights the competing and plural attitudes that inform Turgenev's and Moore's works. Moreover, Pellérdi provides a balanced perspective that is emphasised by her selection of quotations from Turgenev and Moore, and their characters' struggles to articulate their feelings about displacement and the resulting silences.

In the final, and perhaps most exhilarating, part, Keith Hopper, Thierry Robin and Virginie Roche-Tiengo examine the notion of ambivalence, inconclusive ends and the relationships between death, language and silence. Discussing how the process of silencing appears in Flann O'Brien's "John Duffy's Brother" (1949), "Two in One” (1954), The Third Policeman (1968) and An Beal Bocht (The Poor Mouth,1941/1977), Hopper focuses on the complex endings of these works, "and suggests that silence is formally and thematically central" (177). Turning his attention to An Beal Bocht, Hopper demonstrates with exceptional sensitivity that among other things it is a satire on the Gaelic Revival and language revival movement; "Silence arises in this respect in the form of Irish as a language of haunting that may only be capable of being revived in a spectral form; out of its own disappearance" (17). Next, Robin examines a number of lyrics from Dermot Healy's Fool's Errand (2010) and considers numerous philosophers "in addressing the qualities of silence that the collection evokes" (17) in relation to the paradox of combining art and silence. The attention Robin devotes to the forms, style and visual aspects, coupled with his attention to Susan Sontag's aesthetics of silence and Clement Rosset's concept of reality as "idiocy" provides a stimulating analysis that will become essential for readers of Healy's works. Additionally, Robin's essay is both apt and timely given Healy's death in 2014. Similarly, Roche-Tiengo's chapter is timely in the wake of Brian Friel's death in 2015. In "The Voices of the Dead and the Silence of the Living in Brian Friel's Drama", Roche-Tiengo begins her chapter by addressing Friel's drama "in terms of its representation of spiritual and eschatological truths that arise in Irish environments marked by stifled dreams and expectations" (201). The manner in which Roche-Tiengo explores these truths and silences, her employment of Antonin Artaud's notion of theatre as magic and religion and Peter Brook's theory of holy theatre as discussed across a number of Friel's plays attest to a sensitive understanding of his meta-writing, Moreover, Roche-Tiengo is able to foreground Friel's own perspective on silence and language by discussing Give Me Your Answer (1997) in which he "considers another aspect of the language beyond language: the survival of the created work beyond the death of its author" (210). As such, Roche-Tiengo supports her opening assertion that the dead characters are able to speak to the audience from beyond the grave. Much of the pleasure and strength of this chapter is the range of Friel's plays she discusses; from, The Freedom of the City (1973), Living Quarters (1979), Dancing at Lughnasa (1990), Faith Healer (1979) and The Loves of Cass McGuire (1967), instead of relying, as many have done, on yet another examination of Translations (1980).

Despite the positive aspects of this informative collection, there are a number of minor quibbles that detract somewhat from the otherwise insightful series of discussions. Although the volume is devoted to aspects and forms of silence, the wider range of subjects and topics present makes recommending this volume to any specific groups(s) difficult and problematic. The number of essays in this one volume is, at times, distracting and overwhelming, and this is further evident in a number of essays which appear to be underdeveloped or too brief. 
Moreover, this collection employs a concerted level of academic jargon and theoretical terminology, which, at times, makes it appear dense. Given its specialised nature, however, this is an understandable reality, and attests to the level of research conducted by the contributors. Readers with an interest in modern Irish literature, modern drama, fiction and poetry; Postcolonial Studies, Gender Studies, and those interested in psychoanalytical and philosophical approaches to literature will find this a valuable and insightful collection.

\title{
Works cited
}

Glenn, Cheryl. Unspoken: Rhetoric of Silence. Carbondale: Southern Illinois University Press, 2004.

Robert Finnigan obtained his $\mathrm{PhD}$ at the University of Sunderland and is currently researching Anglo- Irish contributions to Aestheticism and Decadence within the fin de siècle period. His primary research interests lie in the areas of Pre- Raphaelitism, Aestheticism, Decadence and the Irish Gaelic Revival, as well as forgotten, neglected and repressed authors. For several years, he has been involved in N.E.I.C.N (North East Irish Culture Network) activities and events to promote and encourage research into the various characteristics of Irish culture and society.

robert.finnigan@sunderland.ac.uk

\author{
Sources and Style in Moore's Irish Melodies \\ Una Hunt \\ London: Routledge, 2017. 190 pp. \\ ISBN: 9781409405610
}

\section{Reviewer: Seán Mac Liam (St Patrick’s College, Dublin City University, Ireland)}

One would have thought that research on the subject of Moore's Irish Melodies had been exhausted and that little of consequence remained to be discovered. However, Una Hunt's latest book not only extends the scholarship on this subject but also contextualizes newly discovered insights within a synthesis of existing knowledge on the topic. Professor Harry White's forward and the author's own introduction set an ambitious expectation of the book that, for the most part, is realized in subsequent chapters. The book is logically structured and includes consideration of Moore as poet, musician and song writer, the political and literary imagery within the song texts, the poet's collaboration with composers Sir John Stevenson and Henry Rowley Bishop, an analytical overview of the songs and a discourse on sources. Her conclusions are original and significant. The work is liberally referenced, contains 66 musical examples in addition to pictorial illustrations and includes a comprehensive appendix of sources, a useful index and a wide-ranging bibliography.

In situating her research within the panoramic context of existing knowledge, the author challenges some accepted beliefs about the melodies. Referring to the militarist and rebellious imagery in the texts and the use of surreptitious code words and motifs redolent of the songs of the United Irishmen, she ponders the association of Moore's songs with Victorian drawing room songs. Although, given the prevalence of folk song arrangements at this time - a lure that attracted even the great Haydn and Beethoven among others - Moore's 
market was essentially the early nineteenth century Irish, Anglo and Anglo-Irish middle and upper classes, and such sentiments would have been perceived to be in poor taste and even traitorous among this clientele. However, in her consideration of "the power of song in promoting ideology" (135), particularly that of the United Irishmen, the author shows how Moore had a particular capacity to conceal such sentiments in songs of love and loss, of minstrelsy and within Irish story and legend of gentler hue. Because of the prevalence of such concealment one might question the extent of awareness of Moore's particular subtext. Hunt's belief, however, is that Moore's texts were so skillfully crafted that their hidden rebel sentiments represented "a tactic of unspoken collusion between all the participants - Moore and the consumers of his songs, both performers and listeners" (27).

The author's re-evaluation of Moore's primary sources extends previous scholarship. Its "most significant conclusion reached is that Holden, and not Bunting, was Moore's most utilized source" (105), thereby undermining many of Bunting's accusations regarding alterations made to the character and tempi of the original source airs. Au contraire, Hunt shows that "the source material used in the Irish Melodies was multifarious, coming from printed collections and manuscripts while other tunes were notated by Moore from memory." (138) Furthermore, Moore was remarkably faithful to the original except where a tune needed to be adapted to best suit its conversion from instrumental to sung mode and "in every case ... Moore drew attention to such substantial amendments in footnotes" (131). Because the Irish Melodies were written as songs, it is the song genre and the interrelationship between words, melody and accompaniment that are central to Hunt's discourse.

One of the more interesting aspects of the book - the composing process involved in creating the Irish Melodies - is curiously the one that might be considered most contentious. Hunt's analysis throughout chapters 2, 3 and 4, is insightful and affirms the consensus view that the songs are better than their reputation suggests. In identifying supporting musical evidence for this belief, the author alludes to various musical features characteristic of art songs that insinuate arguments favouring a reclassification of Moore's songs. This debate is of course an important one given the metaphysical and inspirational nature of the creative process. However, the implication that these essentially parlour songs deserve reclassification as art songs sits somewhat uneasily with an art song's promise of the highest quality and craftsmanship where there is a high degree of musical organization, imaginative interaction and interdependence between poem and music - in short where each element of the mix, composed concurrently, serves a composer's inspired musical vision. While the author's points are undeniable and well made, others might argue that, in the case of the Irish Melodies, these features are neither sufficiently endemically present nor systematically employed throughout the composing process to warrant reclassification - nor could they be, given the distinct and separate involvement over time of each of the parties in the enterprise. Hunt's implication untangles further with the widespread perception of Stevenson's and Bishop's work as unsatisfactory, which led to new settings possessing greater musical significance by William Balfe, Charles Villiers Stanford and Benjamin Britten, among others (4-5).

Considering the central role of composers Stevenson and Bishop in the enterprise, Hunt re-presents the well-established reasons for the bad press accruing in particular to Stevenson. Apart from his failure to engage wholeheartedly with the project resulting in many errors, Stevenson was "caught in a compositional time warp" and "slavishly followed Haydn as his model, even though this approach was patently unsuited to traditional music" (75). The more fastidious Bishop, on the other hand, because he was a more accomplished composer with greater experience in theatre music, was more successful in integrating elements of the melody into his piano parts and, in this way exhibited greater unity within the songs. Hunt also notes a trend, not present in Stevenson's contributions, where in some of the later songs 
"the material used by Bishop in the vocal accompaniments is also altered from one verse to the next, subtly complementing Moore's text and elevating the strophic verse towards a more sophisticated art song" (90). In mimicking aspects of the Romantic art song Bishop's accompaniments offset Stevenson's over-stylized and somewhat careless approach to the piano accompaniments. However, while acknowledging Stevenson's flawed contribution to the solo settings of the melodies, Hunt gives a more positive assessment of the composer's part song arrangements of the airs. "Not only did Stevenson write his more interesting settings for the part songs in the Irish Melodies cycle, he generally took more care over these, as there appear to be fewer printed errors" (67). Because at this time the money followed the prevailing fashion for folk song arrangements for solo voice and piano - hence the initial popularity of Moore's Irish Melodies - Stevenson's part song arrangements were considerably less in demand, although on Hunt's account, they are,

almost without exception, fine compositions providing a snapshot of some of the composer's best work ... Had he been judged on his part song writing, in which he excelled, his reputation might not have been irreparably damaged by the criticism that came his way. (137)

And so, how might future scholarship on Moore's Irish Melodies be accomplished, given the exhaustive and groundbreaking nature of Hunt's research? Curiously, she may have unwittingly given a pointer in her preliminary references to the melodies' afterlife and their positive reception beyond the English-speaking world affirmed by several noted nineteenthcentury translations into French, Spanish, and German. Notwithstanding this, there was at least one attempt to reclaim Moore's work for Gaelic Ireland when in 1871 the Rev John McHale, Archbishop of Tuam, published Irish language translations of selected melodies. In spite of McHale's now largely forgotten translations, and with the growth of the Irish cultural imperative during the early years of the twentieth century, the popularity of Moore's melodies waned chiefly because they were associated with an Anglo-Irish rather than a Gaelic-Irish tradition. During this period, the songs survived extinction by going culturally underground, and re-emerged decoupled from their piano accompaniments during the early years of the Irish Free State as Irish national songs in English. With this newly acquired status, Moore's Irish Melodies were celebrated by an entirely new generation encompassing all social classes although, as befitted the national cultural objectives of the time, it was the song texts rather than the tunes that dictated significance and value. This was especially so during the period 1922 up until the 1960s when Moore's marching songs, laments and songs linked with ancient Irish lore became an indispensible part of the national repertory and were taught in schools the length and breath of the country. Thus, songs like "Avenging and Bright", "The Minstrel Boy", "The Harp that Once through Tara's Halls", "Let Erin Remember the Days of Old", "Tis the Last Rose of Summer", "Believe Me If All Those Endearing Young Charms", "Oh! Breathe Not His Name", "She Is Far From the Land", and "Silent, Oh Moyle!" became cemented into the national repertory.

It is no coincidence that the survival of Moore's input into the project (i.e. tune selection and composition of words) is inversely proportional to the demise of Stevenson's and Bishop's contributions. However, on Hunt's account, this was not a matter of chance because Moore was extremely fastidious in composing words for his chosen tunes. Citing Ronan Kelly's 2008 epic biography Bard of Erin, she reveals Moore's working method:

Of paramount importance was the matching of the pace and manner of the music, as he perceived it, and a surprisingly close bond was achieved between words and text 
through the process of walking and pacing, which were crucial activities in his songwriting process. (35)

In this way, the words emerged naturally to closely fit the configuration of the tune, a characteristic that is noted in most folk songs and this is key to understanding their endurance over time as well as their survival within the national repertory. Hunt's concluding assessment of Moore and his Irish Melodies is relevant.

The alliance between words and music, added to the successful translation from one performance mode to another, must surely mark him out as a songwriter of note. These very qualities continue to ensure that Moore's Irish Melodies will endure as long as Irish song is celebrated. (139)

This was an enjoyable and engaging read. While the author's enthusiasm for her subject shines consistently throughout the book, her complex and deep understanding of her topic is never in doubt, nor is her ability to communicate with clarity and insight.

Seán Mac Liam studied for his BMus degree and a Higher Diploma in Education at University College Cork. He holds an MA in composition and an MLitt in musicology from Trinity College Dublin. He taught in Primary and Post-primary schools, worked as a Music Inspector in the Department of Education and Science. He has recently retired as Associate Professor in Music and Co-ordinator of Humanities Degrees at St Patrick's College, DCU. The author of a number of music textbooks, he has recently completed a monograph on the life and music of Irish nationalist composer Robert O'Dwyer.

sean.macliam@spd.dcu.ie

The Oxford Handbook of Modern Irish Theatre

Edited by Nicholas Grene and Chris Morash

Oxford: Oxford University Press, 2016. 764 pp.

ISBN: 9780198706137

Reviewer: Martine Pelletier (François-Rabelais University, Tours, France)

"There is a story here, a meta-narrative, which is, we believe, hospitable to all the micronarratives that, from time to time, have achieved prominence as the official version of the true history, political and literary, of the island's past and present". It is not hard to imagine that Nicholas Grene and Chris Morash, as they set about editing the wonderful and exciting volume that they have produced with the help of over 40 contributors, may have borne in mind this short extract from Seamus Deane's introduction to the famous Field Day Anthology of Irish Writing. In its own way, what The Oxford Handbook of Modern Irish Theatre provides is indeed a meta-narrative of sorts, based on the transformation of Irish drama into Irish theatre. But it remains hospitable to many micro-narratives such as the role of the Abbey, the professionalization of Irish theatre, the omission and later recognition of women, the place granted to Shaw, Wilde or Beckett in an Irish tradition, the slow recognition that the playwright's text gains from, indeed depends on the work of directors, designers and actors, 
the globalisation of Irish drama. The Oxford Handbook of Modern Irish Theatre is both a comprehensive survey of modern Irish theatre, and a highly reflexive review of changing modes of writing and thinking about modernity/modernism, Irishness and theatre three key terms which all undergo thorough scrutiny though the editors make clear in their introduction that for them, "The most important word in the title of this book is "theatre"". This shift is fully in line with much recent scholarship in the field as the attention of academics and critics has broadened to include not only texts but a wealth of other material. Productions, directors, designers, actors, companies, festivals, theatre spaces, programmes, posters, government agencies, personal archives all get their share of attention in many of the most original and thought-provoking chapters; but many plays, on the page or in performance also receive very insightful analyses. It would be disingenuous to claim that this is the first volume to do so or that this insight into the collaborative and multifaceted nature of theatre is totally revolutionary. But what Grene and Morash succeed in doing here is to broaden the spectrum of academic investigation in a fully comprehensive and convincing manner.

Doing justice to the impressive work of the editors and contributors in a short review is a daunting task: over 750 pages, 41 essays on a range of topics covering the history and practice of Irish theatre from the late $19^{\text {th }}$ to the early $21^{\text {st }}$ centuries, this Oxford Handbook of Modern Irish Theatre is a remarkable scholarly achievement by any standard. The editorial work done is truly outstanding with many welcome and often little-known illustrations, a useful chronology and bibliography; but first and foremost with the division into twelve carefully titled and well-balanced parts which allow the reader to make his/her way through the wealth of material analysed and presented in the volume.

Most of the twelve parts mix the chronological and the thematic and include three or four complementary contributions. There are a few exceptions to this pattern: the first part entitled "Nineteenth-Century Legacies" has only two chapters on melodrama (Stephen Watt) and Oscar Wilde (Michael McAteer), reclaiming both a pre-history for modern Irish theatre in the form of the much disparaged old melodrama, and a key figure of the world stage too often excluded from, or marginalised in, the Irish narrative. The final part, "Critical Responses" is a single challenging essay by Eamonn Jordan synthesizing the rise and fall of modes of critical engagement with Irish theatre and concluding with an exhortation to bridge the gap between academics and practitioners, as well as to encourage more reflexive critical practices.

The four chapters of Part Two, "Theatre and Nation" revisit the influence and importance of the Abbey, first by linking drama and other forms of performance and commitment with the essays by Ben Levitas and P. J. Mathews; then with a careful analysis of Yeats's rituals of performance as challenging the materialist world of modern science by Terence Brown, and finally, Mary Burke's convincing reading of the Playboy riots in juxtaposition with the Paris reception of the controversial ballet, "Rite of Spring", linking Synge and Stravinsky and concluding with Synge as "the Janus of Irish literature, looking backwards to Boucicault and forwards to Irish modernism" (102). Part Three, "Models and Influences", further explores modernism with excellent chapters by Shaun Richards, Richard Cave and Brad Kent. Kent engages in an act of reclamation of G.B. Shaw, arguing for his importance and influence, his "haunting" of many Irish dramatists and intellectuals. "Revolution and Beyond" further engages with the story of the Abbey, Pearse's writings and the Easter Rising, the self-proclaimed National Theatre's relationship with the new State and ends with Christopher Murray's analysis of O'Casey's complex representations of Dublin, from The Harvest Festival to Red Roses For Me through the Dublin trilogy.

It is at this point that "Performance 1" moves firmly into the territory of theatre production. Paige Reynolds, picking up where Richard Cave had left off, authoritatively discusses design and direction; Eibhear Walshe focuses on the "enabling status of Oscar Wilde as house dramatist at the Gate Theatre", with regards to the career of Micheal 
MacLiammoir. Walshe asks whether Wilde the dandy or Wilde the queer artist was/ is most in evidence or acceptable then and now in productions of his plays. Adrian Frazier turns to the actors who performed the many plays discussed earlier; he charts the influence of Antoine's Théâtre Libre on the acting style favoured by the Fay brothers and brings back into the picture Anew McMaster and his connection to the Gate.

The three chapters of "Contesting Voices" deal respectively with Irish language theatre, women and Irish theatre before 1960 and the "little theatres" of the 1950s. Brian O Conchubair examines the ambivalent relationship of the Abbey towards Irish-language plays and discusses the work of several companies and playwrights in and outside Dublin before concluding that "theatre remains a litmus test of Irish as a communal language and public art form". Cathy Leeney brilliantly demonstrates how "the cultural and social value of Irish theatre is enhanced through the inclusion of women playwrights' work" (285). Lionel Pilkington sees the little theatres that flourished mostly in Dublin, but also in Belfast (the 37 Theatre club, the Pike, The Lyric Players...), and performed many plays by non-Irish playwrights as an extraordinary cultural phenomenon which deserves further exploration and confirms the important part played by women like Mary O'Malley and Carolyn Swift in that development.

In its three chapters, "The New Revival" turns to the flowering of Irish drama in the 1960s. Whilst Lisa Coen contrasts the rural and urban cultures informing the works and visions of M.J. Molloy, John B. Keane and Hugh Leonard, Anthony Roche looks in parallel at the two major playwrights of that revival, Tom Murphy and Brian Friel, leaving José Lanters to discuss Thomas Kilroy's "Idea of a Theatre". Both Friel and Murphy reappear in the next section, in different contexts namely that provided by the Derry-based Field Day (with careful research into the Deane, Friel and Field Day archives by Marilynn Richtarik) and the DruidMurphy project analysed by Shelley Troupe. Mark Phelan discusses Troubles and postconflict theatre in Northern Ireland, and convincingly argues that "it is 'change' that has captured the imagination of the new generation of playwrights". Victor Merriman looks at the growth and diversification of Ireland's theatre culture from 1977 to 2000 with the emergence of many independent companies in and outside Dublin, and points to the role of the Arts Council funding in sustaining that diversification.

"Performance 2" takes the reader into less-often charted territory. Chris Morash's piece on places of performance (including some beautiful architects' drawings of never realized theatre buildings) exemplifies the spatial turn taken by some contemporary critics. Ian Walsh surveys the work of directors and designers since 1960 - notably Tomas MacAnna, Joe Dowling, Wendy Shea, Joe Vanek and Patrick Mason); and Nicky Grene's selection of "Defining Performers and Performances" includes Siobahn McKenna and Donal McCann. The final article in this section is devoted to the "re-in-greencarnation" (to borrow Eibhear Walshe's inventive formulation about Wilde at the Gate) of Beckett through the 1991 Beckett festival initiated by Michael Colgan.

Part Ten on "Contemporary Irish Theatre" offers five excellent chapters enabling the reader to understand and connect the most recent evolutions in theatre in Ireland. Helen Hausner Lojek's remarkable essay on McGuinness shows his major plays as so many ways of negotiating differences in terms of nationality, class, gender, sexual orientation and religion, as they are attuned to important changes in late twentieth-century Ireland. Emilie Pine and Clare Wallace highlight both continuities and disruptions. Emilie Pine surveys the plays of Friel (with a strong focus on Dancing at Lughnasa), Murphy, McPherson, Bolger, Roche, Carr and Barry, discussing forms of reconciliation between past and present, tradition and modernity, belonging and exile. Clare Wallace turns to the interpretive challenges thrown at audiences by postmodern playwrights like Mc Donagh, Walsh and O'Rowe. It is up to Melissa Sirha to pick up the thread of women's contribution to contemporary Irish theatre and 
she does so remarkably with analyses of Carr and Charabanc and an acknowledgement of the role played by professionalization and university training in the theatre in "enabling new processes and creativity". In Brian Singleton's masterly piece on devised theatre, what Clare Wallace identified as the new more active role of audiences is further explored with discussion of early proponents of the genre like Operating Theatre, Rough Magic and the Project Arts Center, through companies that foreground physicality (Pan Pan, Blue Raincoat, Barrabas, Corn Exchange) or site-specific work.

Nicholas Grene has been at the origin of the Irish Theatrical Diaspora project and his interest in charting the fortunes of Irish theatre outside Ireland is well-known. It is thus no surprise that the Handbook should end on a section entitled "Ireland and the World". For arguably another meta-narrative at work in the volume from the beginning is the foregrounding of the international or globalized nature of Irish theatre. The six chapters which make up this part address the complex connections between Irish theatre and other theatrical traditions and professional networks. Beckett as a global figure is discussed by Ronan McDonald; the wealth and success of adaptations of foreign classics - Greek tragedy, Chekhov and Ibsen in particular - by Irish playwrights receives insightful analysis by Christina Hunt Mahony. Patrick Lonergan, whose ground breaking work on the globalisation of Irish theatre remains central, looks at the development of the Dublin Theatre Festival and its role in bringing Irish theatre professionals and audiences in contact with the best international companies and plays; John P. Harrington considers the circulation of Irish work in the United States and James Moran focuses on the role played by England, and particularly London, in the economy and international recognition of Irish theatre, as well as focusing attention on plays which engage with forms of Irishness in England.

Ondrej Pilny in many ways has the hardest job in this section, addressing Irish theatre in Europe, since as he points out there is a dearth of material on the subject and academic research into the reception of Irish theatre outside the UK is still too limited or not wellknown. His ground-breaking essay will no doubt encourage the many scholars of Irish theatre in Europe to develop further research in this area, as was done for example with the ITD conference on the interactions of French and Irish theatres which resulted in the publication of a special issue of Etudes irlandaises (2008).

This impressive survey marks a welcome broadening of the spectrum of what Irish theatre is and of what research into Irish theatre can draw on, can do and become, and there is no doubt that this Oxford Handbook of Modern Irish Theatre is a must for anyone with an interest in Irish theatre and culture, as well as a major contribution to the field.

Martine Pelletier is a senior lecturer in English and Irish studies at the University of Tours, France. She has published widely on Brian Friel, Field Day and on contemporary Irish and Northern Irish theatre. She has also written the prefaces of the ten translations into French of Brian Friel's plays by Alain Delahaye, published by L'Avant-Scène Théâtre, Paris. Her two most recent publications are Ireland: Authority and Crisis, with Carine Berbéri, (Bern: Peter Lang, Series: "Reimagining Ireland", vol. 70, 2015), and with Valérie Peyronel, a special issue of Etudes Irlandaises, "Crisis? What Crisis?" (Winter 2015-16).

martine.pelletier@univ-tours.fr 
Modernist Afterlives in Irish Literature and Culture

Edited by Paige Reynolds

London: Anthem Press, 2016. 201 pp.

ISBN: 9781783085736

Reviewer: Melania Terrazas (University of La Rioja, Spain)

Irish modernism is a demanding subject for the contemporary Irish scholar, if for no other reason than the enormous amount of literary, artistic, and critical output of high modernism in Irish literature and culture. If we add to this the large number of themes, forms, and practices of high modernism, and artists' interests in a wide range of cultural practices, the scope of the field keeps on widening. In this context, Modernist Afterlives in Irish Literature and Culture, edited by Paige Reynolds, will be an important contribution to the field. This volume will be of great use both to scholars new to modernism in Irish literature and culture and to most of us who are not hugely familiar with the new perspectives of this influential movement.

The volume addresses the full scope of Irish modernism in the twentieth and twentyfirst centuries. It examines how and why the experimental devices of high modernism keep on appearing in contemporary fiction, poetry, drama, and various cultural practices. The collection's twelve chapters are organized thematically in two sections, and each focuses on a topic relating to Irish modernist writing, a period, a text, or a cultural practice. The first section, "Irish Modernism in Literature and Language", presents a set of essays devoted to specific works of fiction and authors; the second, "Irish Modernism in Institutions, Art and Performance", focuses on various major themes and forms of its cultural practices, in art, design, visual culture, choreography, and theatre. Finally, the book also includes an insightful Afterword by David James in which the scholar proclaims the expansive nature of the volume in terms of scope, interests, and periodization. The index is accurate and complete, and increases the utility of the volume.

The picture of Irish modernism that emerges from this volume is of a multifaceted and multidisciplinary movement. In the first section of the book, several of the essays are devoted to mapping its main aspects, such as formal experimentation or subjectivity, yet also various disciplines, including visual culture or choreography. Thus, the first essay, Anne Fogarty's "A World of Hotels and Gaols", deals with Irish women novelists during the 1930s, whereas Lucy Collins" "I Knew What It Meant/Not to Be at All" tackles experimental Irish women poets in the 1940s and Leah Flack's essay "Whatever is Given/Can Always Be Reimagined" discusses Seamus Heaney's "indefinite modernism".

Within this line of thought, Fogarty identifies aspects of the work of Elizabeth Bowen, Kathleen Coyle, and Pamela Hinkson as belonging to a delayed phase of Irish feminist modernism, whose concerns and self-conscious and radical characteristics contest an aesthetic of a modernism that came after. Fogarty draws attention to how these female novelists depict women as modern subjects who struggle for different roles as a result of the relationship between private and public spheres. Collins studies the radical style of Rhoda Coghill, Mary Devenport O'Neill, and Sheila Wingfield. Their artistic representation of death and dissolution. Such a radical approach allowed them to interrogate the practice of poetry at the time, their own formation and endurance as creative artists, and how difficult it was to adopt a fragmented subjectivity when the female writing self was itself under question. The conclusion is that the modernist afterlife is not a place where these three writers can rest peacefully. These kinds of essays, which provide a diachronic view of Irish modernism as it changed, will be helpful to readers hoping to understand what Irish women writers contributed to the movement. Finally, Flack's shrewd reading of Russian poet Osip 
Mandelstam's modernism not only emphasizes his impact on Seamus Heaney, but also draws attention to the latter's invaluable chance to form new conceptions of his past and extend the influence of his thought, work, ideas and forms to later generations in an unlimited manner.

The other three essays in the first section of the volume convey an idea of Irish modernism as a movement-shifter; it was not the monolithic period it is sometimes thought to be - rather, its themes, forms, and cultivators' arguments can be recognized across the intellectual work of the twentieth and twenty-first century. In this regard, the contribution of Ellen McWilliams, "James Joyce and the Lives of Edna O'Brien", usefully argues that the latter's retelling of Joyce's life is complex and paradoxical because she shows herself to be very much aware of the politics of the canon of Joyce's biography, and yet still adopts an irreverent and casual manner dependent on her own writing interests and commitments. McWilliams concludes that O'Brien has always maintained a careful balance of power with her most important modernist siblings. In the next essay, "Modernist Topoi and Late Modernist Praxis in Recent Irish Poetry", Alex Davis addresses the relevance of poetry presses in advancing the aims of procedural poets like David Lloyd, whose appropriation of earlier modernist practices differs from the thematically significant deployment of modernist topoi one witnesses in, for instance, Mahon and Heaney. Finally, Sarah McKibben's "“Amach Leis!' (Out with It!)" traces modernist inheritances in Micheál Ó Conghaile's "Athair", and the result is a challenge to traditional views of Irish-language writing of the late nineteenth century and early twentieth century, which has always been associated with revival and as being incompatible with modernism. On the contrary, McKibben argues that prose writers of the Gaelic Revival like Máirtin Ó Cadhain, Myles na gCopaleen, or Ó’Conghaile not only shared crucial preoccupations with modernism, but also advanced many experimental forms. For this reader, one of the most fascinating aspects of the volume is how many different varieties of Irish modernism appear across its pages.

Modernist Afterlives is also particularly valuable for its contributions on Irish modernist culture. The second section, "Irish Modernism in Institutions, Art and Performance", starts with an essay by Andrew A. Kuhn ("Make a Letter Like a Monument") that offers an engaging, readable overview of modernist institutions in print culture and the publishing world that created and sustained literature in Ireland. By focusing on how certain publishers, like Cuala, Dun Emer, or Dolmen Press, fully embraced valuable Irish modernist strategies and experiments, Kuhn shows that they contributed to remaking the literary world of the day, enlarging the international reputation of their writers, and conceptualizing Irishness within a cosmopolitan framework. Kuhn's essay is illustrated with six reproductions of early and mid-to-late twentieth-century books by W. B. Yeats, including In the Seven Woods, The Cat and the Moon and Certain Poems, the Yeats Centenary Papers MCMLXV, and the 1950s Ten Poems by Padraic Colum, which contribute to a further understanding of the subject. This piece is complemented by Róisín Kennedy's essay on Irish modernist art ("Storm in a Teacup"), which usefully explores contemporary Irish artists' ambivalent attitudes to this subject. Here, Kennedy compares the enthusiastic embrace of Irish modernist art by contemporary collectors and institutions in Ireland to the stance of contemporary artists, as they preferred to evoke the more subversive practices found in international avant-garde art rather than those of Irish modernist art. Illustrations include a 3-minute loop image from Dorothy Cross' Teacup (1997), Michael Farrell's lithograph Madonna Irlanda (1977), Louis le Brocquy's oil on canvas A Family (1951), or Sean Scully's oil in linen Figure in Grey (2004). The traces of modernism found in contemporary Irish artists' work, Kennedy argues, offer a surprising remedy to the frequent association of Irish modernism to the Celticism of the past and a way of reclaiming a more accurate understanding of the radical inquiry of the present that lies at the core of modernist forms. 
Linda King's "Particles of Meaning" investigates the modernist afterlife in Irish design during the twentieth century, including branding, architecture, and book design, among other areas. She points to four figures from the 30s to the late 50s, Michael Scott, Stella Steyn, Jan de Fouw, and Alvin Lustig, and asserts the relevance of migration to the production of exciting new forms that spoke to indigenous and foreign audiences, as well as to the development of modern and contemporary Irish design. Maria Pramaggiore's "Animal Afterlives: Equine Legacies in Irish Visual Culture" traces representations of the horse in twentieth- and twenty-first-century visual media, focusing primarily on the qualities of this animal's afterlives to transcend our sense of modernist temporality. The last two essays, by Aoife McGrath ("Choreographies of Irish Modernity") and Emilie Pine ("The Modernist Impulse in Irish Theatre"), contribute particularly interesting accounts of how contemporary performances in Ireland are reminiscent of modernism in their search to represent and understand trauma. McGrath explores the relevance of Yeats's dance play At the Hawk's Well (1916) to Fearghus Ó Conchúir's solo dance performance Cure (2013) and offers a fuller account of how the comparison of these two works by Irish artists separated by $a$ hundredyear gap contributes to not only the illumination of discussions of modernity and dance, but also helps to determine links between the body practices researched and performed by Ó Conchúir and the choreographers of Cure, the space thus created provides an alternative affective experience that allows the audience to understand their everyday life in a corrupted, but not incurable, Irish society. Pine, for her part, shows that the well-known Monto tetralogy of plays produced by Anu Productions (a site-specific Dublin theatre company run by director Louise Lowe and visual artist Owen Boss) - World's End Lane (2010), Laundry (2011), The Boys of Foley Street (2012), and Vardo Corner (2014) - set in particularly economically deprived inner-city areas, consistently disrupts the detachment frequently associated with modernist work, yet, in staging trauma, echoes the modernists working in post-war contexts, like Brecht, Jarry, or Beckett, and their commitment to form as meaning, as a form of expressing and comprehending trauma.

Modernist Afterlives in Irish Literature and Culture seeks to assist both established and new scholars of Irish modernism as they come to terms with the full extent of Irish modernist achievements. Editor Paige Reynolds is to be praised for assembling a fairly varied group of scholars to produce essays, and for designing this volume to ensure deep and wide coverage. This is a clear and concise collection that highlights significant thought and areas of debate. It provides many examples of theoretical investigation in the hope that readers will find Irish modernist literature and culture engaging. Modernist Afterlives will be a welcome addition to university libraries, and will benefit postgraduate students and professors who teach or research Irish modernist literature and culture.

Melania Terrazas is Senior Lecturer in English Studies in the Department of Modern Languages, University of La Rioja. She is the author of Relational Structures in Wyndham Lewis's Fiction: Complexity and Value (2005) and has published on applied linguistics and on British modernism. She was previously editor of the Journal of English Studies and is on the Executive Board of AEDEI (The Spanish Association for Irish Studies) and a founding member of the Centre for Irish Studies BANNA/BOND (EFACIS). She is currently a visiting scholar at NUI Galway.

melania.terrazas@unirioja.es 